\title{
The Correlation between EFL Students' Use of ICT Level and Their Autonomous Learning Level
}

\section{Korelasi antara Penggunaan TIK dengan Tingkat Otonomi Belajar Mahasiswa Bahasa Inggris sebagai Bahasa Asing}

\author{
Devon Evita, Siti Muniroh*, Nunung Suryati \\ Universitas Negeri Malang, Jl. Semarang No. 5 Malang, Jawa Timur, Indonesia \\ *Penulis korespondensi, Surel: siti.muniroh.fs@um.ac.id
}

Paper received: 23-09-2021; revised: 07-11-2021; accepted: 21-11-2021

\begin{abstract}
Information and Communication Technology is a basic need for life nowadays, including education. Many people believe that ICT can promote students' autonomous learning. Thus, this study was conducted to find whether ICT usage and autonomous learning are correlated, and to compare the attitudes between Indonesian and Moroccan EFL students. This study used quantitative correlational design. The participants were 97 English Department students of Universitas Negeri Malang. The instrument was a questionnaire with 28 items: 14 questions for ICT usage and 14 (items/questions) for autonomous learning. The data were analyzed using Pearson Product Moment Correlation Coefficient in SPSS 25 application. The findings revealed that ICT usage and autonomous learning are correlated. The other findings are Indonesians EFL students like to have discussions with peers, while Moroccans like to look for information themselves. Moreover, Indonesians have very high selfawareness and low self-confidence, meanwhile Moroccans have very high self-effort and autonomy in planning. This study brings significance to teaching practice to inform how far ICT usage contributes to autonomous learning, especially in the Covid-19 outbreak. The researcher recommended that future researchers widen the participants' total and use the other variables outside this study's variables since ICT usage only contributes $22.1 \%$ to autonomous learning.
\end{abstract}

Keywords: ICT use; autonomous learning; EFL students.

\begin{abstract}
Abstrak
Teknologi Informasi dan Komunikasi merupakan kebutuhan dasar di kehidupan jaman sekarang, termasuk pendidikan. Banyak orang percaya bahwa TIK dapat memicu otonomi belajar siswa. Maka dari itu, penelitian ini diadakan untuk menemukan korelasi antara penggunaan TIK dan otonomi belajar siswa serta membandingkan sikap mahasiswa Bahasa Inggris sebagai Bahasa Asing Indonesia dengan Maroko. Penelitian ini menggunakan desain korelasi kuantitatif. Pesertanya adalah 97 mahasiswa jurusan Sastra Inggris Universitas Negeri Malang. Instrumennya menggunakan kuesioner yang terdiri dari 28 item, 14 untuk penggunaan TIK dan 14 untuk otonomi belajar. Data dianalisis menggunakan Pearson Product Moment Correlation Coefficient pada aplikasi SPSS 25. Hasilnya, penggunaan TIK dan otonomi belajar saling berhubungan. Temuan lainnya yaitu mahasiswa Indonesia suka berkomunikasi dengan teman, sedangkan mahasiswa Maroko suka mencari informasi sendiri. Selain itu, mahasiswa Indonesia memiliki kesadaran diri yang sangat tinggi dan kepercayaan diri yang rendah, sedangkan mahasiswa Maroko memiliki kemandirian dan otonomi perencanaan yang sangat tinggi. Penelitian ini membawa signifikansi pada praktik mengajar karena menginformasikan sejauh mana penggunaan TIK berkontribusi terhadap belajar mandiri, terutama di masa wabah Covid-19. Peneliti merekomendasikan peneliti selanjutnya untuk memperluas total peserta dan menggunakan variabel lain di luar variabel penelitian ini karena penggunaan TIK hanya berkontribusi $22,1 \%$ terhadap belajar mandiri.
\end{abstract}

Kata kunci: penggunaan TIK; belajar mandiri; siswa bahasa Inggris sebagai bahasa asing. 


\section{Introduction}

Information and Communication Technology (ICT) now has become a basic need in modern society. People must at least master basic skills to use technology; students and teachers are not the exceptions. According to UNESCO (n.d.), ICT is a "diverse set of technological tools and resources used to transmit, store, create, share or exchange information". It includes computers, internet, telephone, live and recorded broadcasting technologies. In addition, according to Blurton (1999, as cited in Oussou, 2020b), ICT is defined as a "diverse set of technological tools and resources used to communicate, create, disseminate, store, and manage information". Nowadays, students can easily search for school materials on the internet. Moreover, students can learn something new every day, and they do not need to wait for teachers to explain first. Students take control of their learning process and have more access to further information that cannot be controlled by their teachers when using technology (Gilakjani \& Sabouri, 2013). In addition, students who are concerned about learning a second language through ICT as a tool can be reinforced with the skill developments of listening, understanding, reading, and writing in English (Gómez, Alcántar, Torres, Montes, \& Padilla, 2018). Another thing is that their assignments mostly require ICT to be done. Meanwhile, for teachers, ICT should be used maximally to make the atmosphere of the learning and teaching process more up-to-date and relatable to students, already Generation $\mathrm{Z}$ and below, who are growing up and with technology (Linnes \& Metcalf, 2017).

ICT is a need for education nowadays. ICT can be helpful for education because it can guide students to access digital information, promote a creative learning environment and student-centered learning, offer opportunities to develop critical thinking, improve and facilitate learning and teaching atmosphere (Chouthaiwale \& Alkamel, 2018). Moreover, in EFL (English as a Foreign Language) in university context, it can help students easily learn Englishspeaking countries' culture, such as United States, United Kingdom, etc., and improve their language skills (Sibi, 2020).

Many people believe that ICT can promote independent learning/autonomous learning for students (Budianto, 2014; Melvina, Lengkanawati, \& Wirza, 2021). Autonomous learning is a term that people usually know as independent learning or self-directed learning. Autonomous learning has been a concern in the education world, including EFL. This term was first introduced by Holec (1981, as cited in Oussou, 2020a, p. 157)). He defined autonomous learning as "the ability to take charge of one's learning". It implies that students can be called autonomous learners or have autonomous learning when they have been able to take full responsibility for their learning style at their own pace that they can enjoy.

As it is known, autonomous learning is essential to be applied in education because it can improve students' learning quality (Tomasouw \& Marantika, 2020). One of the alternatives is by using ICT as the medium. ICT can improve students' motivation, self-engagement, and commitment, promote independent learning, improve collaboration and communication between students-students and students-teachers, and finally, it makes students' achievements improved (Ariza \& Sánchez, 2013). ICT promotes effective use for students' learning, students' individualized instructions, and students' ability to find information by themselves (Falck, Mang, \& Woessmann, 2018). In line with that, ICT lets students have freedom and flexibility in learning according to their own pace and ease (Ghasemi \& Hashemi, 2011). Furthermore, using ICT can lead students to develop self-understanding and creativity 
because it provides enjoyable and exciting ways to learn language by themselves (Ahmadi, 2018). In summary, the findings show that ICT correlates autonomous learning positively.

Some studies related to ICT use and autonomous learning have been conducted by some researchers (Ariza \& Sánchez, 2013; Oussou, 2020b). Ariza and Sánchez (2013) investigated the effectiveness of ICT and activities incorporation towards students' awareness of learning autonomy in the context of Universitaria Colombo Americana (UNICA), Columbia. The research was action research, focusing on students' activities such as decision making, independent practice, and the development of metacognitive processes to study English using ICT tools. Ariza and Sánchez (2013) gathered data from students' perceptions of the effectiveness of the activities, reflections, and students' performances in their English class. The result showed that the activities within the context of basic-level language learning, which used ICT tools, positively impact students' performance.

The second study was done by Oussou (2020b) from the University of Moulay Ismail, Morocco, investigating the effectiveness of EFL Students' Use of ICT in Developing their Autonomy. The research was conducted with a total of $109 \mathrm{EFL}$ (English as a Foreign Language) undergraduate students who took part in the study. The result shows that the higher the level of ICTs' use of the students, the higher the degree of their autonomy is reported. Oussou (2020b) concluded that students' ICT use level is significantly related to their degree of autonomy.

In the current study, the researcher intended to replicate Oussou's (2020b) study to verify whether ICT use is significantly related to students' autonomy in an Indonesian university. The current study was conducted during the Covid-19 outbreak in which the learning was conducted online and involved ICT use highly. Thus, the researcher believed the current study brings significance to teaching practice as it informs the extent to which ICT usage can be related to autonomous learning about how far ICT usage contributes to autonomous learning since Oussou's (2020b) study did not include this finding. Following the purpose of the study, the researcher also wanted to compare the results of the current study with the results of the study conducted by Oussou (2020b) in the contexts of Moroccan EFL students. There may be some differences between how ICT usage and EFL students' autonomous learning correlate with each other in Morocco and Indonesia, although both use English as a foreign language.

\section{Methods}

The current study employs a correlational research design since it describes the quantitative degree to which variables are related (Latief, 2017). The variables are students' ICT use level and their autonomous learning level. The participants are English Department students (2020, 2019, and 2018 cohorts) in Universitas Negeri Malang (UM). Latief (2017) stated that "the data in correlational design are analyzed using statistics resulting in correlation coefficient which shows the degree of the relationship between variables involved." The researcher would use statistics and scatter diagrams to show the scores of both variables and see the relationship between the variables involved.

The study participants were 97 English Department students of UM, and they were students of 2020, 2019, and 2018 cohorts. The researcher chose English Department UM students because the students have experienced Independent Study (a course) in their first semester, so they must be familiar with learning activities that should be done independently 
with just a little lecturers' instructions in the beginning. The lecturers let the students choose whatever learning style and materials they want, which is one of the practical definitions of autonomous learning. Moreover, they were familiar with ICT since they were in an era in which ICT is a must tool to do assignments since high school, or they could be simply mentioned as digital natives.

The questionnaire was developed in Google Form to gather information about; 1) participants' self-information, 2) ICT usage that aims to measure students' use of ICT level, and 3) autonomous learning to measure students' autonomous learning level.

The first part of the questionnaire deals with demographic information of the participants, such as their gender and cohort. The second part of the questionnaire was adapted from Missoum's (2015) scale about self-improvement, peer and teaching communication, and using internet related to study. It consists of 16 questions about ICT usage in learning English. For the third part, the researcher used a different learner's autonomy scale from the previous research conducted by Orakci and Gelişli (2017). The scale's setting in Orakci and Gelişli's (2017) study is general or for normal learning situation, while this research's scale is for distance learning situation that is required to be applied in this COVID-19 pandemic. The researcher took the instrument for the second part, which is about autonomous learning adapted from Bei, Mavroidis, and Giossos' (2020) scale. It consists of 14 questions, and the questions are about students' difficulties in management, self-awareness, autonomy in action, and autonomy in planning. The researcher modified some questions so that the questions can be understood easily by the respondents. She also used the Indonesian language since a good questionnaire should be not confusing, ambiguous and should use familiar vocabulary to respondents so that the respondents have uniformity of understanding (Kabir, 2016). It is also better to use the respondents' first language, in this case, is Indonesian, because it does not need more time to translate and understand the language (Cortazzi, Pilcher, \& Jin, 2011).

The researcher used Likert Scale for the answers, which consist of 4 options: strongly agree, agree, disagree, and strongly disagree. The total from the second and third part is 30 questions. If a respondent chooses number 1 , which strongly disagrees, the score is 1 . If a respondent chooses number 2 , the score is 2 , and so on. The maximum score is 120 and the minimum score is 30 .

The questionnaire was shared online via messenger platforms such as WhatsApp and Line. Before that, the researcher made the questionnaire in Google Form, then shared the link through WhatsApp (private and group chats). She also explained the topic and the purpose briefly. She ensured the respondents understood every word and sentence in the questionnaire before they filled in the questionnaire by providing brief autonomous learning's definition and her e-mail address to be contacted if the respondents didn't not understand the questionnaire enough.

The instrument was tested first to see whether it is valid and reliable using SPSS 25 software. Then, the researcher conducted a normality test to see whether the data was normally distributed. The next step was regression analysis which consisted of T-test, to find whether ICT usage partially contributes to autonomous learning; F-test which ICT usage simultaneously contributes to autonomous learning; and $\mathrm{R}^{2}$-test which aims at finding how far ICT usage contributes to autonomous learning. Finally, the data were analyzed using Pearson Product Moment Correlation Coefficient formula manually and through SPSS 25 software to 
analyze the correlation between two variables. Pearson Product Moment Correlation Coefficient was used because the data of both variables were in the form of quantitative scores and the data are in interval scale. According to Chee (2015), Pearson Product Moment Correlation Coefficient is used to "measure the strength, direction, and probability of the linear association between two interval or ratio variables". In this research, it measures the strength and direction of the correlation between students' use of ICT level with their autonomous learning level.

The formula of Pearson Product Moment Correlation Coefficient is:

$$
r=\frac{n \Sigma X Y-(\Sigma X)(\Sigma Y)}{\sqrt{\left[n \Sigma X^{2}-(\Sigma X)^{2}\right]\left[n \Sigma Y^{2}-(\Sigma Y)^{2}\right]}}
$$

$\mathrm{r}=$ Pearson Product Moment Correlation coefficient of $\mathrm{X}$ and $\mathrm{Y}$ variables

$\mathrm{n}=$ total number of the samples

$\mathrm{X}=$ the independent variable/the first variable mean

$\mathrm{Y}=$ the dependent variable/the second variable mean

In order to determine the correlation between the two variables, the current study employed a null hypothesis $\left(\mathrm{H}_{0}\right)$ and an alternative hypothesis $\left(\mathrm{H}_{\mathrm{a}}\right)$. The researcher tested the hypothesis to find the result of the research, whether the null hypothesis is accepted or rejected. Null hypothesis $\left(\mathrm{H}_{0}\right)$ means that there is no correlation between two variables or the correlation is not significant. The hypothesis testing is done at an alpha level of 0.05 . The criteria to accept, or reject the null hypothesis are defined below.

If calculated Sig. (2-tailed) $<0.05$, the null hypothesis is rejected

If calculated Sig. (2-tailed) $>0.05$, the null hypothesis is accepted

Alternatively, if using the variables in the current study, it would be:

If calculated Sig. (2-tailed) $<0.05$, there is a correlation between students' use of ICT level and their autonomous level

If calculated Sig. (2-tailed) >0.05, there is no correlation between students' use of ICT level and their autonomous level

\section{Findings and Discussion}

\subsection{The Correlation between Students' ICT Usage and Their Autonomous Learning Level}

Before testing the correlation, the researcher conducted several tests to make sure the instrument is valid and reliable and whether the data have normal distribution or not. A validity test was conducted to know the validity of the instrument. The result is that all items of the autonomous learning part are valid. However, there are two items of ICT usage that are not valid, which are item X4 "I use computers to write my homework/papers." with the significance of 0.078 and X12 "I read documents on screen (Smartphone/computer)." with the significance of 0.55 (for clearer data, kindly look at appendix 2). Because those two items' significances are $>0.05$, thus, the researcher deleted both invalid items from the data to not affect and spoil the following process and satisfy the construct validity criteria (Taherdoost, 
2016). The researcher then re-tests the data's validity without the invalid items, and the result of all data is valid.

Next, a reliability test was also conducted to know whether the reliability of the data. The result is presented in Tables 1 and 2 below.

Table 1. Case Processing Summary

\begin{tabular}{cccc}
\hline \multicolumn{4}{c}{ Case Processing Summary } \\
\hline \multirow{3}{*}{ Cases } & & $\mathrm{N}$ & $\%$ \\
\cline { 2 - 4 } & Valid & 97 & 100.0 \\
\cline { 2 - 4 } & Excluded $^{\mathrm{a}}$ & 0 & .0 \\
\cline { 2 - 4 } & Total & 97 & 100.0 \\
\hline
\end{tabular}

a. Listwise deletion based on all variables in the procedure.

At first, the planned subject total was only 90 , but the respondents seemed more enthusiastic in filling the questionnaire than expected. Thus, the table above informs that the total of respondents (N) is 97 people. Since all items are filled, so the valid data is $100 \%$.

Table 2. Reliability Statistics

\begin{tabular}{cc}
\hline \multicolumn{2}{c}{ Reliability Statistics } \\
\hline Cronbach's Alpha & N of Items \\
\hline .830 & 28 \\
\hline
\end{tabular}

The output table of Reliability Statistics above shows that the total items of the questionnaire are 28 items, and the Cronbach's Alpha value is 0.830. An instrument is considered reliable or consistent if the Cronbach's Alpha is 0.70 or above (van Griethuijsen et al., 2015). Since the Cronbach's Alpha value which is 0.830 is more than $0.70(0.830>0.70)$, thus, it can be concluded that all items in the instrument are reliable or consistent.

The next test is a normality test that checks whether the data distribution is normal. The result is shown in Table 3 and Figure 1.

Table 3. The Result of Normality Test

\begin{tabular}{|c|c|c|}
\hline \multicolumn{3}{|c|}{ One-Sample Kolmogorov-Smirnov Test } \\
\hline \multicolumn{3}{|c|}{ Unstandardized Residual } \\
\hline $\mathrm{N}$ & & 97 \\
\hline \multirow{2}{*}{$\begin{array}{l}\text { Normal } \\
\text { Parameters }{ }^{\mathrm{a}, \mathrm{b}}\end{array}$} & Mean & .0000000 \\
\hline & Std. Deviation & 4.65332962 \\
\hline \multirow{3}{*}{$\begin{array}{l}\text { Most Extreme } \\
\text { Differences }\end{array}$} & Absolute & .077 \\
\hline & Positive & .035 \\
\hline & Negative & -.077 \\
\hline \multicolumn{2}{|l|}{ Test Statistic } & .077 \\
\hline \multicolumn{2}{|c|}{ Asymp. Sig. (2-tailed) } & $.182^{\circ}$ \\
\hline \multicolumn{3}{|c|}{$\begin{array}{l}\text { a. Test distribution is Normal. } \\
\text { b. Calculated from data. } \\
\text { c. Lilliefors Significance Correction. }\end{array}$} \\
\hline
\end{tabular}




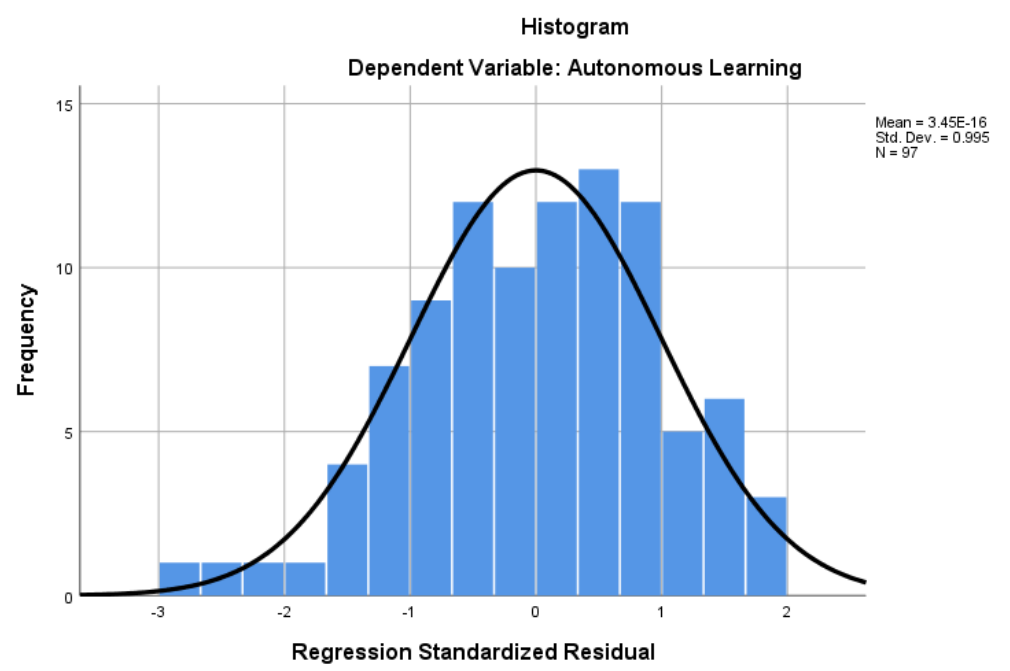

Figure 1. Histogram Graphic of Normality Test

The output table of One-Sample Kolmogorov-Smirnov Test as seen in Table 3 above shows that the significance value (Sig.) of all variables is 0.182 . Sig. 0.182 is more than 0.05 $(0.182>0.05)$, and this indicates that all data is normally distributed (Gissane, 2015). As can be seen in Figure 1, the histogram graphic's shape is like a bell, and this indicates that all data is normally distributed.

Next, regression analysis which consists of T-test, F-test, and R2-test was conducted. The first test was T-test which aims at finding whether ICT usage partially contributes to autonomous learning. The result is shown in Table 4 below.

Table 4. The Result of T-Test

\begin{tabular}{|c|c|c|c|c|c|c|}
\hline \multicolumn{7}{|c|}{ Coefficientsa $^{a}$} \\
\hline \multirow{2}{*}{\multicolumn{2}{|c|}{ Model }} & \multicolumn{2}{|c|}{$\begin{array}{l}\text { Unstandardized } \\
\text { Coefficients }\end{array}$} & \multirow{2}{*}{$\begin{array}{c}\text { Standardized } \\
\text { Coefficients } \\
\text { Beta }\end{array}$} & \multirow[t]{2}{*}{$\mathrm{t}$} & \multirow[t]{2}{*}{ Sig. } \\
\hline & & B & Std. Error & & & \\
\hline \multirow[t]{3}{*}{1} & (Constant) & 22.488 & 3.938 & & 5.71 & .00 \\
\hline & & & & & 0 & 0 \\
\hline & ICT Usage & .473 & .091 & .470 & 5.19 & .00 \\
\hline
\end{tabular}

a. Dependent Variable: Autonomous Learning

From the output table of SPSS Coefficients above, the significance value is 0.000 which is less than $0.050(<0.050)$, which indicates that the null hypothesis $\left(\mathrm{H}_{0}\right)$ is rejected and the alternative hypothesis $\left(\mathrm{H}_{\mathrm{a}}\right)$ is accepted. Thus, there is a significant contribution of ICT usage to autonomous learning. Thus, it can be concluded that ICT usage partially and significantly contributes to autonomous learning.

It also can be seen from Table 4 above that the constant value (a) is 22.488 , meanwhile, the ICT usage (b) value is 0.473 . The regression formula can be written as:

$$
\begin{aligned}
& Y=a+b X \\
& Y=22.488+0.473 X
\end{aligned}
$$


The interpretation of the formula result of the t-test is; 1 ) the unstandardized coefficient value (a) is 22.488, which means if ICT usage (X) is zero ( 0 ), the consistent value of autonomous learning $(\mathrm{Y})$ is 22.488. If it is inputted to the formula, it would be $22.488+0.473(0)=22.488$, and 2) the coefficient regression value (b) is 0.473 , which means that any 1 value increase of ICT usage, will also increase autonomous learning (Y) equal to 0.473 . For example, if the ICT usage value increases by 1 , it would be $22.488+0.473(1)=22.961$. Then, if the value increases by 2 , the result $(22.961)$ just needs to be added by $0.473(22.961+0.473)$, and multiples.

The second test is F-test which aims at finding whether ICT usage simultaneously contributes to autonomous learning. The result can be seen in Table 5 below.

Table 5. The Result of F-Test

\begin{tabular}{|c|c|c|c|c|c|c|}
\hline \multicolumn{7}{|c|}{ ANOVA $^{a}$} \\
\hline Model & & $\begin{array}{c}\text { Sum of } \\
\text { Squares }\end{array}$ & & Mean Square & $\mathrm{F}$ & Sig. \\
\hline \multirow[t]{3}{*}{1} & Regression & 589.720 & 1 & 589.720 & 26.951 & $.000^{\mathrm{b}}$ \\
\hline & Residual & 2078.734 & 95 & 21.881 & & \\
\hline & Total & 2668.454 & 96 & & & \\
\hline
\end{tabular}

a. Dependent Variable: Autonomous Learning

b. Predictors: (Constant), ICT Usage

From the output table of SPSS ANOVA above, the significance value is 0.000 which is less than $0.050(<0.050)$, indicating that the null hypothesis $\left(\mathrm{H}_{0}\right)$ is rejected and the alternative hypothesis $\left(\mathrm{H}_{\mathrm{a}}\right)$ is accepted. Thus, there will be a significant contribution of ICT usage to autonomous learning. Hence, it can be concluded that ICT usage simultaneously and significantly contributes to autonomous learning.

The third and the last test in regression analysis is $\mathrm{R}^{2}$-test which aims at finding how far ICT usage contributes to autonomous learning which is shown in Table 6 below.

Table 6. The Result of $\mathbf{R}^{2}$-Test

\begin{tabular}{ccccc}
\hline \multicolumn{5}{c}{ Model Summary } \\
\hline Model & $\mathrm{R}$ & R Square & Adjusted R Square & Std. Error of the Estimate \\
\hline 1 & $.470^{\mathrm{a}}$ & .221 & .213 & 4.678 \\
\hline
\end{tabular}

a. Predictors: (Constant), ICT Usage

The output table of SPSS Model Summary above shows that the $\mathrm{R}^{2}$ value is 0.221 or $22.1 \%$. This means that ICT usage simultaneously contributes to autonomous learning to the extent of 0.221 or $22.1 \%$. The rest $(77.9 \%)$ is contributed by other factors or variables outside this regression equation or outside the variable in the current study.

After all those steps, finally, the researcher tested the correlation which aims at testing whether the variables are correlated or not. With the $\sum \mathrm{X}$ is $4,150, \sum \mathrm{Y}$ is $4,166, \sum \mathrm{XY}$ is 179,484 , $\sum \mathrm{X}^{2}$ is 180,220 , and $\sum \mathrm{Y}^{2}$ is 181,564 , the result can be seen at the formula below and Table 4 .

$$
\begin{gathered}
r=\frac{n \Sigma X Y-(\Sigma X)(\Sigma Y)}{\sqrt{\left[n \Sigma X^{2}-(\Sigma X)^{2}\right]\left[n \Sigma Y^{2}-(\Sigma Y)^{2}\right]}} \\
r=\frac{97(179,484)-(4,150)(4,166)}{\sqrt{\left[97(180,220)-(4,150)^{2}\right]\left[97(181,564)-(4,166)^{2}\right]}}
\end{gathered}
$$




$$
\begin{gathered}
r=\frac{17,409,948-17,288,900}{\sqrt{(258,840)(256,152)}} \\
r=\frac{121,048}{257,492.5} \\
r=0.470
\end{gathered}
$$

Table 7. Pearson Product Moment Correlation Coefficient

\begin{tabular}{llrr}
\hline \multicolumn{1}{c}{ Correlations } & & \\
\hline & & ICT Usage & \multicolumn{1}{c}{$\begin{array}{c}\text { Autonomous } \\
\text { Learning }\end{array}$} \\
\hline \multirow{2}{*}{ ICT Usage } & Pearson Correlation & 1 & $.470^{* *}$ \\
\cline { 2 - 4 } & Sig. (2-tailed) & 97 & .000 \\
\cline { 2 - 4 } & $\mathrm{N}$ & $.470^{* *}$ & 97 \\
\hline Autonomous Learning & Pearson Correlation & .000 & 1 \\
\cline { 2 - 4 } & Sig. (2-tailed) & 97 & 97 \\
\cline { 2 - 4 } & $\mathrm{N}$ & & \\
\hline \multirow{2}{*}{ **. Correlation is significant at the 0.01 level (2-tailed) } & & \\
\cline { 2 - 4 } & &
\end{tabular}

The output table of Pearson Product Moment Correlation Coefficient shows that the significance value (Sig.) is 0.000 which is less than $0.05(0.000<0.05)$. It means that both variables are correlated. In this case, students' ICT usage level is correlated with their autonomous learning level. In addition, as can be seen in the manual formula result and the output table of Pearson Product Moment Correlation Coefficient above, the $r$ value (Pearson Correlation value) result is 0.470 which is the same as shown in Table 7 above.

Table 8. Pearson Correlation " $r$ " Value Interpretation

\begin{tabular}{cc}
\hline $\begin{array}{c}\text { Absolute Magnitude of the Observed } \\
\text { Correlation Coefficient }\end{array}$ & Interpretation \\
\hline $0.00-0.10$ & Negligible correlation \\
\hline $0.10-0.39$ & Weak correlation \\
\hline $0.40-0.69$ & Moderate correlation \\
\hline $0.70-0.89$ & Strong correlation \\
\hline $0.90-1.00$ & Very strong correlation \\
\hline
\end{tabular}

According to Table 8 (Schober \& Schwarte, 2018) above, the $r$ value, which is 0.470 , of the current study correlation is moderate. Moreover, if the $r$ value is 0.470 , it also can be mentioned as +0.470 which means that the direction is positive or has the same direction. Figure 2 also shows that the plot dots form a straight-line pattern from the bottom left to the top right which means the direction is positive. Thus, it indicates that the more students use ICT, the more they will learn autonomously. 


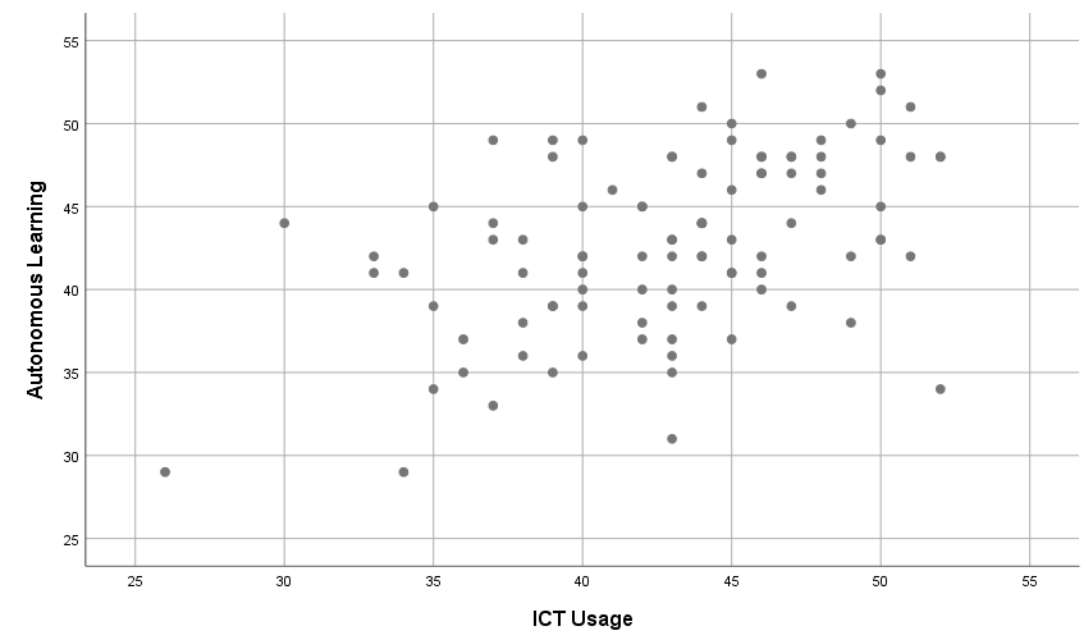

Figure 2. Scatter Diagram

\subsection{Findings in The Results of The Instrument}

\subsubsection{The Extent of Students' ICT Usage in Learning English}

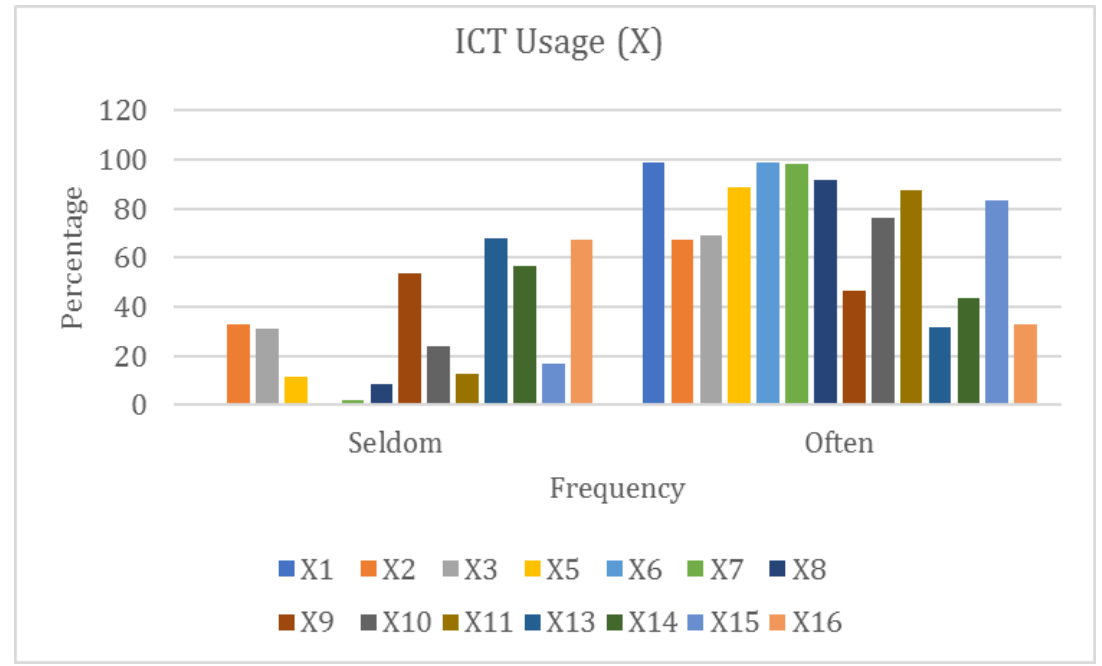

Figure 3. Graphic of ICT Usage Level in Terms of Frequency

From Figure 3 about the result of students' ICT usage level above, X1 (item 1) which is "I use the Internet to connect with other learners for learning (sharing experiences, questions and answers, documents related to learning)" and X6 (item 6) which is "I search for / find information / documents I need on the Web" are the highest items rated that are often done by students with a percentage of $99 \%$. Following them, the next highest rated items are X7 "I chat with other students about learning assignment, etc.", X8 "I practice English using websites such as YouTube, British Council, etc.", X5 "While writing on the computer, I use automatic error detection (grammar and spelling check) to correct language mistakes", and X11 "I look up new concepts / terms in electronic dictionaries and encyclopedias" with the percentages of $97.9 \%$, $91.8 \%, 88.7 \%$, and $87.7 \%$ respectively. Meanwhile, the highest items rated that are seldom done are X13 "I record lessons / lectures and listen to them (for revision)", X16 "I record myself (audio or video) to find out what I need to improve in my English speaking / presentation 
skills", and X14 "I ask for feedback / advice by email or official university website from my teachers and supervisors" with the percentages of $68.1 \%, 67 \%$, and $56.7 \%$ respectively. The data tells that the respondents mostly prefer communicating and having discussions with peers to their teachers/lecturers.

\subsubsection{The Extent of Students' Autonomous Learning in Learning English}

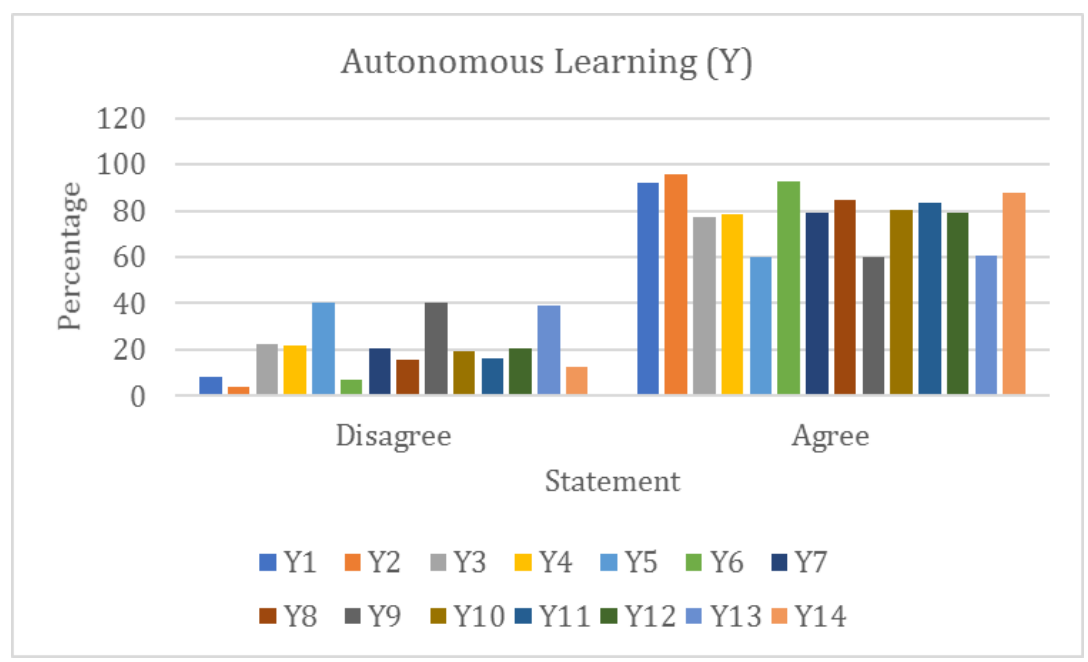

Figure 4 . Graphic of Autonomous Learning Level in Terms of Disagreement and Agreement

From Figure 4 about the result of students' autonomous learning level, it can be inferred that the highest degree item in terms of agreement is Y2 "I am aware of my limits in relation to my English study" with a percentage of 95.9\%. The following highest degree items are Y6 "I seek alternative solutions when a difficult problem emerges in my English study", Y1 "I am aware of my abilities in relation to my English study", Y14 "I want my tutor to let me act on my own", and Y8 "I set realistic learning goals that meet my needs", with the percentages of $92.8 \%$, $91.8 \%, 87.6 \%$, and $84.5 \%$ consecutively. Meanwhile, the highest degree items in term of disagreement are Y5 "I can manage any problem that may arise in my English study", Y9 "I plan in detail the steps I should take in order to pursue my goals", and Y13 "I can self-evaluate my learning in total", with the percentages of $40.2 \%, 40.2 \%$, and $39.2 \%$ consecutively. The data tells that the respondents have a high self-awareness, but low self-confidence.

\subsection{Discussions}

As showed, the result of the students' use of ICT level and their autonomous learning level is positively and significantly correlated. Thus, this finding confirmed the previous study finding by Oussou (2020b).

Besides, the current study also aims at finding if there is something different or similar with previous studies, especially with Oussou's (2020b) study which has Moroccan background. The current study's data result of ICT usage shows that the highest frequency in using ICT is using the internet to connect with peers to share something related to English and to search/find information/documents that students need on websites, with both having the percentages of 99\%. This finding of the current study is almost the same as Oulmaati, Ezzahri, and Samadi's (2017) finding which found that their respondents use ICT the most to communicate with peers to share ideas, documents, and information related to the course. 
However, Hafa and Moubtassime (2021) found that communicating with peers about courserelated things is the ninth most rated activity, out of twelve activities which also means this activity has a low frequency. Although Oussou (2020b) found that the tendency of his respondents' ICT usage is directed towards YouTube videos explaining concepts related to English, the second most tendency is searching/finding information/documents that students need which are still considered as high-frequency activity, almost as high as the current study's finding. The next highest frequency activity of the current study is chatting with peers about assignments (97.9\%) which means that the students like to have discussions with peers while doing their assignments because they may think that working together is easier and faster. The fourth highest frequency activity (91.8\%) is practicing English using media such as YouTube and British Council which implies that EFL students often try to improve their English skills. In addition, those websites are simple, easy to be accessed anytime, and easy to operate. Although the label is English as Foreign Language (EFL) students, they are still learning how to write something with minimum errors. Thus, they also often use automatic error detection while writing their documents, which has a frequency percentage of $88.7 \%$.

The current study's respondents seem to have big self-awareness for the autonomous learning section since the highest-rated item is about being aware of their limits in learning English, which is a good thing. Moreover, being aware of their abilities also becomes the third highest-rated item. This means that they can sense what they can improve and develop in learning English. Meanwhile, Khaidir, Tersta, and Afria (2020) found that their respondents tend to have low self-esteem. They mostly note their strengths and weaknesses and try to improve them just sometimes, while almost half of Oussou's (2020b) respondents did not try to improve their weaknesses. Next, seeking alternative solutions while studying is the secondhighest-rated item (91.8\%), which means that the current study's respondents tend to have high self-effort or autonomy in action. They may feel like they have a responsibility to finish their English studies, so they always try to seek alternative solutions rather than give up. They also want the freedom to act on their own learning, which has a percentage of $87.6 \%$. This finding is in line with Ariebowo's (2021) study. This may be because the current and Ariebowo's (2020) study's respondents feel they are their own director and they know exactly what to do to pursue their objectives/goals. The other thing is while the current study found that setting learning goals is the fourth highest-rated item (84.5\%), Oussou (2020b) found that it is the highest rated item (82.6\%) in his study. This may mean that setting learning goals is not a priority for the current study's respondents, while Oussou's (2020b) respondents consider it as a crucial one.

On the other hand, the current study found that the three most seldom done by the respondents in using ICT are recording lecture/lesson to be re-learned and for revision, recording themselves to find where they lack in their speaking/presentation skills and asking for feedback/advice from lecturers/supervisors. Recording lectures/lessons may need quite a lot of storage, so students are reluctant to do that. They may only take notes or just listen and remember the lecture. Next, most of the respondents seldom record themselves to find where they lack in their speaking/presentation skills. Most of them may be too reluctant to re-listen to their recording or they may find it takes much time, so they choose to practice without recording it and will immediately correct themselves when they make mistakes. The respondents also seem to have very limited communication with their lecturers since they seldom ask for feedback/advice from lecturers. This finding is in line with Oulmaati, Ezzahri, 
and Samadi's (2017); Oussou's (2020b); and Hafa and Moubtassime's (2021) studies which revealed that the students, indeed, rarely communicate with teachers/lecturers regarding their learning issues.

Unexpectedly, pertinent to autonomous learning, the current study also found that the respondents seem to have less self-confidence in managing problems that may arise in their study, which is the item with the most disagreement (40.2\%). This percentage is the same with planning steps in detail to pursue their goals. They may not like to detail everything, but they just want to go spontaneously. This is followed by self-evaluation, which has a high disagreement. Khotimah et al. (2019) revealed that although the evaluating process is in a good category, it also means almost close to the lowest score. Moreover, Oussou (2020b) also revealed that evaluating progress has a low rate of agreement. Some people may have a hard time evaluating themselves, but they must do it to improve their self-quality. Moreover, the current study's respondents are college students who already have to take full control of their own learning.

\section{Conclusion}

Based on the current study's results, some conclusions are drawn. First, the current study reveals that students' ICT usage and their autonomous learning level are positively and significantly correlated. The $r$ and significance value are 0.470 and 0.000 , means that the correlation has a positive direction and moderate relationship. That is to say, the higher students' use of ICT level, the higher students' autonomous learning level is. The null hypothesis was rejected and the alternative hypothesis was accepted. Therefore, the current study verified the previous studies. Second, when the students use ICT more, the more they will study autonomously. It implies that students need ICT in their learning process. Not only for students, but almost all aspects in this life also need ICT as a tool to work/study.

Last, since the respondents here are only 97 and limited to English Department UM students $(2018,2019$, and 2020 cohorts), the researcher was aware that the current study could not represent all Indonesian ELT students. Thus, the researcher hope the future researchers would widen the participants' total and area representing Indonesia as a whole. The additional analysis about how far the contribution of ICT usage to autonomous learning was also conducted revealed that ICT usage simultaneously contributes to autonomous learning to the extent of $22.1 \%$. It means that the rest (77.9\%) or other variables outside the current study are not included. Thus, future researchers also can identify the other variables that can contribute to autonomous learning. Since the instrument here was limited to questionnaire, the researcher also suggested that future researchers add more instruments, such as interview, to strengthen the findings. The researcher also hoped for the high school teachers and university lecturers to increase the ICT usage to promote students' autonomous learning since nowadays students are already familiar with and interested in ICT.

\section{References}

Ahmadi, D. M. R. (2018). The use of technology in English language learning: A literature review. International Journal of Research in English Education, 3(2), 115-125. doi: 10.29252/ijree.3.2.115

Ariebowo, T. (2021). Autonomous learning during Covid-19 pandemic: Students' objectives and preferences. Journal of Foreign Language Teaching and Learning, 6(1), 56-77. doi: 10.18196/ftl.v6i1.10079

Ariza, A., \& Sánchez, M. S. (2013). Effectiveness of the integration of ICT tools and activities to foster awareness as the first stage to reach learning autonomy. Gist Education and Learning Research Journal, 7(7), 154172. Retrieved from http://files.eric.ed.gov/fulltext/EJ1102672.pdf 
Bei, E., Mavroidis, I., \& Giossos, Y. (2020). Development of a scale for measuring the learner autonomy of distance education students. European Journal of Open, Distance and E-Learning, 22(2), 133-144. doi: 10.2478/eurodl-2019-0015

Budianto, L. (2014). Promoting students' autonomous learning through ICT based learning in ICP: A case study. LiNGUA: Jurnal Ilmu Bahasa Dan Sastra, 9(2). doi: 10.18860/ling.v9i2.2734

Chee, J. (2015). Pearson's Product Moment Correlation Coefficient (PPMCC). Bourne Mouth University. Retrieved from https://media3.bournemouth.ac.uk/spss/focus_pages/focus_10a.htm

Chouthaiwale, D. S. S., \& Alkamel, M. A. (2018). The positive effect of ICT on the English language learning and teaching. Dialoguing Borders: Vital Issues in Humanities, Commerce, IT and Management, 1(November), $1-8$. Retrieved from https://www.researchgate.net/publication/329572075_The_positive_Effect_of_ICT_on_the_English_La nguage_Learning_and_Teaching

Cortazzi, M., Pilcher, N., \& Jin, L. (2011). Language choices and 'blind shadows': Investigating interviews with Chinese participants. Qualitative Research, 11(5), 505-535. doi: 10.1177/1468794111413225

Falck, O., Mang, C., \& Woessmann, L. (2018). Virtually no effect? Different uses of classroom computers and their effect on student achievement. Oxford Bulletin of Economics and Statistics, 80(1), 1-38. doi: 10.1111/obes.12192

Ghasemi, B., \& Hashemi, M. (2011). ICT: Newwave in English language learning/teaching. Procedia - Social and Behavioral Sciences, 15, 3098-3102. doi: 10.1016/j.sbspro.2011.04.252

Gilakjani, A. P., \& Sabouri, N. B. (2013). Role of Iranian EFL teachers about using pronunciation power software in the instruction of English pronunciation. English Language Teaching, 7(1), 139-148. doi: $10.5539 /$ elt.v7n1p139

Gissane, C. (2015). Is the data normally distributed? Physiotherapy Practice and Research, 37(1), 57-60. doi: 10.3233/PPR-150069

Gómez, M. L. M., Alcántar, M. del R. C., Torres, C. I., Montes, J. F. C., \& Padilla, A. A. J. (2018). Use of ICT for learning the English language. IJAEDU- International E-Journal of Advances in Education, 4(11), 192-198. doi: $10.18768 /$ ijaedu. 455621

Hafa, H., \& Moubtassime, M. (2021). The use of ICT in learning English: A study of students in Moroccan universities. SAR Journal - Science and Research, 4(1), 19-28. doi: 10.18421/SAR41-04

Kabir, S. M. S. (2016). Basic guidelines for research: An introductory approach for all disciplines. In Theoretical Economics Letters (First). Chittagong-4203, Bangladesh: Book Zone Publication. Retrieved from https://www.scirp.org/reference/referencespapers.aspx?referenceid=2789552\%0Ahttps://www.rese archgate.net/publication/325846997_METHODS_OF_DATA_COLLECTION

Khaidir, F., Tersta, F. W., \& Afria, R. (2020). Students' perception of autonomous learning activities. J-SHMIC: Journal of English for Academic, 7(1), 66-76. doi: 10.25299/jshmic.2020.vol7(1).4599

Khotimah, K., Widiati, U., Mustofa, M., \& Ubaidillah, M. F. (2019). Autonomous English learning: Teachers' and students' perceptions. Indonesian Journal of Applied Linguistics, 9(2), 371-381. doi: 10.17509/ijal.v9i2.20234

Latief, M. A. (2017). Research Methods on Language Learning: An Introduction (Sixth). Malang: Universitas Negeri Malang.

Linnes, C., \& Metcalf, B. (2017). iGeneration and their acceptance of technology. International Journal of Management \& Information Systems (IJMIS), 21(2), 11-26. doi: 10.19030/ijmis.v21i2.10073

Melvina, Lengkanawati, N. S., \& Wirza, Y. (2021). The use of technology to promote learner autonomy in teaching English. Proceedings of the Thirteenth Conference on Applied Linguistics (CONAPLIN 2020), 546, 315-321. doi: 10.2991/assehr.k.210427.048

Missoum, M. (2015). ICT use and EFL learner autonomy -student questionnaire. doi: 10.13140/RG.2.2.11890.15047

Orakci, Ş., \& Gelişli, Y. (2017). Learner autonomy scale: A scale development study. Malaysian Online Journal of Educational Sciences, 5(1), 25-36. Retrieved from https://eric.ed.gov/?id=EJ1156953

Oulmaati, K., Ezzahri, S., \& Samadi, K. (2017). The use of ICT in the learning process among the students of History and Civilization at Abdelmalek Essaadi University, Morocco. International Journal of Scientific 
Engineering and Research, 8(2), 972-979. Retrieved from https://hal.archives-ouvertes.fr/hal01512370

Oussou, S. (2020a). Promoting learner autonomy. International Journal of Language and Literary Studies, 2(2), 156-167. doi: 10.36892/ijlls.v2i2.278

Oussou, S. (2020b). The effectiveness of EFL students' use of ICT on developing their autonomy. Journal of Studies in Language, Culture and Society (JSLCS), 3(1), 89-101. Retrieved from https://www.researchgate.net/publication/342924060_The_Effectiveness_of_EFL_Students'_Use_of_IC T_in_Developing_their_Autonomy

Schober, P., \& Schwarte, L. A. (2018). Correlation coefficients: Appropriate use and interpretation. Anesthesia and Analgesia, 126(5), 1763-1768. doi: 10.1213/ANE.0000000000002864

Sibi, K. J. (2020). English language skills through ICT methods. Sparkling International Journal of Multidisciplinary Research Studies, 3(July), 31-36. Retrieved from https://www.researchgate.net/publication/343058414_ENGLISH_LANGUAGE_SKILLS_THROUGH_ICT_ METHODS

Tomasouw, J., \& Marantika, J. E. R. (2020). Learner autonomy as strategy to enhance the quality of learner. Proceedings of the 3rd International Conference on Learning Innovation and Quality Education (ICLIQE 2019), 397, 504-510. doi: 10.2991/assehr.k.200129.063

UNESCO. (n.d.). Information and communication technologies (ICT). Retrieved November 7, 2020, from http://uis.unesco.org/en/glossary-term/information-and-communication-technologies-ict

Van Griethuijsen, R. A. L. F., van Eijck, M. W., Haste, H., den Brok, P. J., Skinner, N. C., Mansour, N., ... BouJaoude, S. (2015). Global patterns in students' views of science and interest in Science. Research in Science Education, 45(4), 581-603. doi: 10.1007/s11165-014-9438-6 